\title{
Chemical and physical characteristics of local lecithin in comparison with some other food emulsifiers
}

\author{
By Y. El-Shattory, Salwa B. El-Magoli * , S.H. Abu-Ria * and M.G. Megahed \\ Fats and Oils Dept., National Research Centre, Dokki, Cairo. Egypt. \\ * Food Technology Dept., Faculty of Agriculture, Cairo University, Egypt.
}

\section{RESUMEN}

Características quimicofísicas de lecitina local en comparación con otros emulsionantes alimentarios.

Se estudiaron las características químicas y físicas de lecitina local y otros emulsionantes alimentarios (Emulfuid $\mathrm{E}$, Triodan $\mathrm{R} 90, \mathrm{~Pa}$ nodan 150 y Monoestearato de glicerol). Las características de estos emulsionantes estudiados fueron solubilidad, balance hidrófilo-lipófilo (HLB), índice de estabilidad (SI), composición en ácidos grasos y espectros de infrarrojo. Los resultados obtenidos mostraron que Emulfuid $E$ y lecitina local fueron mezclas de lecitinas y fosfatidil etanolamina. Por otro lado, Triodan R 90 fue ester poliglicerídico del ácido ricinoleíco; Panodan 150 una mezcla de mono y diglicéridos y G.M.S. un ester monoglicerídico del ácido esteárico.

PALABRAS-CLAVE: Emulsionante alimentario - Lecitina - Propiedades físicas - Propiedades químicas.

\section{SUMMARY}

Chemical and physical characteristics of local lecithin in comparison with some other food emulsifiers.

The chemical and physical characteristics of local lecithin and other food emulsifiers (Emulfuid E, Triodan R 90, Panodan 150 and Glycerol mono stearate) were studied. The characteristics of these emulsifiers studied were solubility, hydrophile-lipophile balance (HLB), stability index (SI), fatty acid composition and infrared spectrum. The results obtained showed that Emulfuid $\mathrm{E}$ and local lecithin were mixture of lecithins and phosphatidyl ethanol-amine. In addition, Triodan $\mathrm{R} 90$ was a polyglycerol ester of ricinoleic acid, Panodan 150 was a blend of mono and diglycerides, and G.M.S. was a monoglycerol ester of stearic acid.

KEY-WORDS: Chemical properties - Food emulsifier - Lecithin - Physical properties.

\section{INTRODUCTION}

The industrialization of food production, which has taken place in this century, has created a demand for food processing aids such as food emulsifiers. The function of these minor ingredients in foods is to facilitate large-scale, highly automated production of uniform products with longer stability (shelf-life) which can stand transport and storage until consumption takes place (Krog, 1992). An emulsifier is a substrate with a hydrophobic and a hydrophilic part that has the capacity to form water-in-oil (w/o) or oil-in-water (o/w) emulsions by reducing the interfacial tension. Food products consist not only of water and oil but also of proteins, carbohydrates and other component. Therefore, the term "emulsifier» is to be understood in a much wider sense as surface active agent. The formula for the various phospholipids indicated that the hydrophobic and hydrophilic parts are balanced and that lecithin can be used as an emulsifier (Pearce and Kinsella, 1978). Lecithins, having both polar and non polar groups, have high surface activity and are reactive with both oil and protein, making it an excellent emulsifying agent in food systems (Cherry and Gray, 1981). The objective of the present study were to compare between the chemical and physical properties of local lecithin with some imported emulsifiers.

\section{MATERIALS AND METHODS}

\section{Emulsifiers}

a) Local lecithin (L.Le) was obtained locally from Sandab Factory of Misr Company for Oil and Soap, Egypt.

b) Emulfuid $E$ (E.E.) was obtained from Lucas Mayer Company, Germany.

c) Triodan R 90 (T. R 90) and Panodan 150 (P. 150) were obtained from Grindsted Company, Denmark.

d) Glycerol Mono Stearate (G.M.S.) was obtained from Brimer Food Company, Germany.

e) Other solvents and chemicals used were obtained from British Drug House (BDH).

Hydrophilic-lipophile balance (HLB) of emulsifiers was calculated using the equation of Griffin (1965). Stability index (SI) was determined by the method of Titus et al., (1968). The chromatographic analysis of fatty acids was performed according to Farag et al., (1986). While the infrared spectra of emulsifiers were performed according to Farag et al., (1977). 


\section{RESULTS AND DISCUSSION}

Chemophysical results of local lecithin and other food emulsifiers are tabulated in tables from I to IV. It has shown that: a) These emulsifiers are nearly soluble in diethyl ether, $n$-hexane and oil but are not soluble in either water or ethanol, these results agree with that of Akoh and Swanson, (1989), Feuge et al., (1970) and El-Shattory et al., (1993). Table I shows these results.

Table I

Solubility of emulsifiers in different solvents

\begin{tabular}{|c|c|c|c|c|c|c|}
\hline \multirow{2}{*}{ Solvent } & \multirow{2}{*}{ Temp ${ }^{\circ} \mathrm{C}$} & \multicolumn{5}{|c|}{ Emulsifiers } \\
\hline & & Emulfuid E & Local lecithin & Triodan R 90 & Panodan 150 & Glycerol mono stearate \\
\hline \multicolumn{7}{|l|}{ Water } \\
\hline & 25 & 1 & 1 & 1 & 1 & 1 \\
\hline & 75 & PS & ss & i & ss & i \\
\hline \multicolumn{7}{|l|}{ Diethyl ether } \\
\hline & 25 & $s$ & $s$ & $s$ & $s$ & $\mathrm{~s}$ \\
\hline & 75 & $\mathrm{~s}$ & $\mathrm{~s}$ & $s$ & $\mathrm{~s}$ & $\mathrm{~s}$ \\
\hline \multicolumn{7}{|l|}{ P. ether $(60 / 80)$} \\
\hline & 25 & $s$ & $\mathrm{~s}$ & $s$ & PS & 1 \\
\hline & 75 & $\mathrm{~s}$ & $\mathrm{~s}$ & $s$ & PS & PS \\
\hline \multicolumn{7}{|l|}{ n-hexane } \\
\hline & 25 & $s$ & $s$ & $s$ & ss & 1 \\
\hline & 75 & $\mathrm{~s}$ & $\mathrm{~s}$ & $\mathrm{~s}$ & $\mathrm{~s}$ & $s$ \\
\hline \multicolumn{7}{|l|}{ Oil } \\
\hline & 25 & PS & $s$ & PS & 1 & 1 \\
\hline & 75 & $s$ & $\mathrm{~s}$ & $s$ & PS & $s$ \\
\hline \multicolumn{7}{|l|}{ Ethanol } \\
\hline & 25 & I & 1 & 1 & 1 & 1 \\
\hline & 75 & ss & ss & ss & PS & $s$ \\
\hline
\end{tabular}

Where:

I = Insoluble

$\mathrm{PS}=$ Partially soluble

SS $=$ Springly soluble

$\mathrm{S}=$ Soluble

b) HLB of local lecithin and Emulfuid E was almost the same, while, on the other hand Panodan 150 and Triodan R 90 had higher HLB. Meanwhile (G.M.S.) have the lowest HLB. These varied HLB values (from 3.3 to 10.5) depending on emulsifiers chemical composition (Ebeler and Walker, 1984). Table II shows this relation.

c) Stability index increased with the increase of oil percentage. Meanwhile, (G.M.S.), Emulfuid $E$ and local lecithin (strongly lipophilic) are tended to make more stable water-in-oil (w/o) emulsions in comparison with Triodan R 90 and Panodan 150 (strongly hydrophilic). (Akoh and Nwosu, 1992). Increasing the amount of emulsifiers caused an increases in the stability index of the emulsions at all levels of concentration. These actions are attibuted to the reduction of interfacial tension between the two phases of emulsion (Cullum, 1992). Table III shows these actions.
Table II

Hydrophile-lipophile balance (HLB) of emulsifiers

\begin{tabular}{cc}
\hline Emulsifier & HLB $^{*}$ \\
\hline Emulfuid E & 6.8 \\
Local Lecithin & 7.1 \\
Triodan R 90 & 8.3 \\
Panodan 150 & 10.5 \\
Glycerol mono stearate & 3.3 \\
\hline
\end{tabular}

* Hydrophile-lipophile balance $=20(1-\mathrm{S} / \mathrm{A})$

Where:

$\mathrm{S}=$ Saponification value.

$A=A c i d$ value of the total fatty acids of the samples after hydrolysis. 
Table III

Stability index (S.I.) of soybean oil-water emulsions with emulsifiers at different concentrations

\begin{tabular}{|c|c|c|c|c|c|c|c|}
\hline \multirow[b]{2}{*}{ Emulsifier } & \multicolumn{7}{|c|}{$\%$ soybean oil } \\
\hline & $\%$ & 15 & 30 & 45 & 60 & 75 & 90 \\
\hline \multirow{4}{*}{ Emulfuid $\mathrm{E}$} & \multicolumn{7}{|c|}{ Stability index } \\
\hline & 1 & 13.00 & 25.50 & 25.50 & 85.80 & 96.20 & 100.10 \\
\hline & 3 & 60.60 & 80.40 & 97.60 & 90.40 & 97.20 & 101.60 \\
\hline & 5 & 55.10 & 78.90 & 84.60 & 92.40 & 98.30 & 105.50 \\
\hline \multirow{3}{*}{ Local lecithin } & 1 & 12.20 & 13.50 & 94.70 & 101.10 & 98.50 & 99.40 \\
\hline & 3 & 18.40 & 20.20 & 99.60 & 99.40 & 99.90 & 96.50 \\
\hline & 5 & 19.60 & 20.90 & 99.10 & 99.10 & 99.50 & 100.80 \\
\hline \multirow{3}{*}{ Triodan R 90} & 1 & 17.90 & 63.60 & 94.20 & 98.70 & 97.00 & 98.90 \\
\hline & 3 & 51.70 & 78.10 & 95.10 & 93.70 & 99.80 & 98.20 \\
\hline & 5 & 77.10 & 87.80 & 92.60 & 95.20 & 101.60 & 99.20 \\
\hline \multirow{3}{*}{ Panodan 150} & 1 & 21.20 & 27.30 & 36.10 & 40.90 & 64.20 & 83.30 \\
\hline & 3 & 36.10 & 62.00 & 92.80 & 95.30 & 96.00 & 97.10 \\
\hline & 5 & 35.20 & 79.90 & 96.10 & 95.90 & 98.20 & 100.40 \\
\hline \multirow{3}{*}{ Glycerol mono-stearate } & 1 & 13.90 & 12.20 & 10.50 & 18.30 & 72.00 & 85.30 \\
\hline & 3 & 59.30 & 84.10 & 95.40 & 99.10 & 99.60 & 102.00 \\
\hline & 5 & 78.40 & 89.20 & 97.00 & 99.00 & 100.80 & 102.00 \\
\hline
\end{tabular}

Where:

* Stability index (S.I.) $=($ Fat $\%$ in the bottom half of the sample $) /$ (Fat $\%$ of the total sample $) \times 100$.

d) Fatty acid contents of local lecithin, Emulfuid E and Triodan R 90 were $(55.5 \%, 64.2 \%$ and $76.1 \%)$ of unsatured fatty acids, and $(44.5 \%$, $35.8 \%$ and $23.9 \%$ ) of satured fatty acids. Stearic acid forms more than $75.0 \%$ and $68.0 \%$ of the fatty acids of Panodan 150 and (G.M.S.), respectively. These results are in agreement with that Akoh and Swanson (1989) and Calahoro et al., (1992). Table IV shows fatty acids composition of these emulsifiers.

e) The infrared spectrum for lecithin revealed the presence of a peak at $1720 \mathrm{~cm}^{-1}$ corresponding to the ester carbonyl of the glicophosphatide. Meanwhile, the presence of a peak at $970 \mathrm{~cm}^{-1}$ is an indication for choline containing phospholipids. These peaks have been also reported by Pizzoli et al., (1967) for soybean lecithin. The infrared spectrum also showed peaks at $1500 \mathrm{~cm}^{-1}$ for bending $\left(\mathrm{C}-\mathrm{H}, \mathrm{CH}_{2}\right.$ and $\left.\mathrm{CH}_{3}\right)$ at $1190 \mathrm{~cm}^{-1}(\mathrm{P}$ $=\mathrm{O})$, at $1160 \mathrm{~cm}^{-1}$ for $(\mathrm{C}-\mathrm{O}-\mathrm{C})$ and at 1090 $\mathrm{cm}^{-1}$ for ( $\left.\mathrm{P}-\mathrm{O}\right)$. On the other hand, a peak at $1080 \mathrm{~cm}^{-1}$ was also believed to arise form
(P-O-C) vibration and one at $1180 \mathrm{~cm}^{-1}$ form a (C-O-C) linkage (Marinette and Stotz, 1953). Meanwhile phosphatidyl ethanol amine and phosphatidyl serine of lecithin posses the fatty ester grouping gives strong $C=O$ bound of peak about $1750 \mathrm{~cm}^{-1}$. These results are in agreement with those reported by Scholfield (1981) and Hurst and Marin (1984).

The infrared spectrum of Triodan R 90 and Panodan 150 showed clearly the alcoholic esters, free $\mathrm{OH}$ group and carboxylic acids at peaks 3350 $\mathrm{cm}^{-1}$ and $1720 \mathrm{~cm}^{-1}$. In infrared spectrum of (G.M.S.) the peak at $3350 \mathrm{~cm}^{-1}$ is attributed to the free $\mathrm{OH}$-stret-ching. While, the peak at $1720 \mathrm{~cm}^{-1}$ indicated the presence of carbonyl ester and the peak at $1500 \mathrm{~cm}^{-1}$ is characterized for bending $(\mathrm{C}-\mathrm{H})$, $\left(\mathrm{CH}_{2} \mathrm{O}\right)$ and $\left(\mathrm{CH}_{3}\right)$ (Dollear, 1959). GLC analyses and I.R. spectra proved that Emulfuid $E$ and local lecithin are mixture of lecithins and phosphatidyl ethanol-amine. While, Triodan $R 90$ ia a polyglycerol ester of ricinoleic acid, and Panodan 150 is a blend of mono and diglycerides. Meanwhile, (G.M.S.) is a monoglycerol ester of stearic acid. 
Table IV

Fatty acids composition of emulsifiers

\begin{tabular}{|c|c|c|c|c|c|c|}
\hline \multirow{2}{*}{ Emulsifier } & \multicolumn{6}{|c|}{ Fatty acids $\%$} \\
\hline & $C_{14: 0}$ & $C_{16: 0}$ & $C_{18: 0}$ & $C_{18: 1}$ & $C_{18: 2}$ & $\mathrm{C}_{18: 1(\mathrm{OH})}$ \\
\hline Emulfuid $\mathrm{E}$ & 0.23 & 16.06 & 19.47 & 44.73 & 19.51 & 0.00 \\
\hline Local lecithin & 3.47 & 17.89 & 23.13 & 47.82 & 7.69 & 0.00 \\
\hline Triodan R 90 & 12.11 & 3.03 & 8.78 & 31.49 & 0.00 & 44.59 \\
\hline Panodan 150 & 7.00 & 13.71 & 75.99 & 3.30 & 0.00 & 0.00 \\
\hline Glycerol mono stearate & 29.47 & 2.45 & 68.08 & 0.00 & 0.00 & 0.00 \\
\hline
\end{tabular}

Where:

$\mathrm{C}_{14: 0}=$ Myristic

$\mathrm{C}_{16: 0}=$ Palmitic

$\mathrm{C}_{18: 0}=$ Stearic

$\mathrm{C}_{18: 1}=$ Oleic

$\mathrm{C}_{18: 2}=$ Linoleic

$\mathrm{C}_{18: 1(\mathrm{OH})}=$ Ricinoleic

\section{REFERENCES}

1. Akoh, C.C. and Swanson, B.G. (1989).-—Preparation of trehalose and sorbitol fatty acid polyesters by interesterification".-J. Am. Oil Chemists Soc. 66 (11), 1581-1587.

2. Akoh, C.C. and Nwosu, C.V. (1992).- - Emulsification properties of polyesters and sucrose ester blends II: Alkyl glycoside polyesters".-J. Am. Oil Chemists Soc. 69 (1) 14-19.

3. Calahorro, C., Muñoz, J., Berjano, A., Guerrero, A. and Gallegos C. (1992).- "Flow behaviour of sucrose stearate/water systems".-J. Am. Oil Chemists'Soc. 69, 660-666.

4. Cherry, J.P. and Gray, M.S. (1981).— «A review of lecithin chemistry and glandless cottonseed as a potential commercial source".-J. Am. Oil Chemists'Soc. 58, 903-913.

5. Cullum, D.C. (1992)._- «ntroduction to surfactant analysis".-Published by: Blackie Academic and Professional, an imprint of Chapman and Hall, Wester Cleddens Road. Bishopnriggs, Glasgow G64 2NZ, UK.

6. Dollear, F.G. (1995).- «Proceeding of conference on chemical structure and reactions of gossypol and nongossypol pigments cottonseed".-U.S.D.A., New Orleans, USA.

7. Ebeler, S.E. and Walker, C.E. (1984)._- «Effects of various sucrose fatty acid ester emulsifiers on high-ratio white layer cakes".-J. Food Science 49, 380-383.

8. El-Shattory, Y., Aly, S.H. and Megahed, M.G. (1993)."Conference of Gums and Stabilixers for Food Industry».-Oxford Univ., Press, Watton St., Oxford, OX2 60P, England.
9. Farag, R.S., Abdel-Malek, G.S. and Salib, A.G. (1977).Chem. Microbiol Technol. Lebensm.

10. Farag, R.S., Hallabo, S.A.S., Hewedi, M. and Basyony, A.E. (1986). - «Chemical evaluation of rapeseed".Fette Seifen Anstrichmittel 88 (10), 391-397.

11. Feuge, R.O., Zeringue, H.J., Weiss, T.J. and Brown, M. (1970). - «Preparation of sucrose esters by interesterification".-J. Am. Oil Chemists'Soc. 47, 56-60.

12. Griffin, W.C. (1965). - «Encyclopedia of Chemical Technology".-Vol. 8, 117-154, Interscience Publishers, New York, London, Sydney.

13. Hurst, W.J. and Martin, R.A. (1984).— «The analysis of phospholipids in soy lecithin by HPLC».-J. Am. Oil Chemists'Soc. 61, 1462-1463.

14. Krog, N.J. (1992).- - Emulsions - a Fundamental and Practical Approach".-61, 74. J. Sioblom (ed) Klumer Academic Publisher. Netherlands.

15. Marinetti, G. and Stotz, E. (1998).-J. Am. Oil Chemists'Soc 75, 310.

16. Pearce, K.N. and Kinsella, J.E. (1978)._- «mulsifying properties: Evaluation of a turbidimetric technique".J. Agric. Food Chem. 26, 716-723.

17. Pizzoli, E.M., De Manco, O. and Natarnicola, L. (1967).Grasse 44 62, C.F.: C.A. 67. 118-402.

18. Scholfield, C.R. (1981)._ «Composition of soybean lecithin».-J. Am. Oil Chemists Soc 58, 889-891.

19. Titus, I.C., Wianko, N.N., Barbour, H.F. and Mickle, J.B. (1968).- - Emulsifier efficiency in model systems of milk fat or soybean oil and water".-Food Technology 22, 115-117. 